\title{
Species-specific house productivity of appendicularians
}

\author{
Riki Sato $^{1,2, *}$, Yuji Tanaka ${ }^{1}$, Takashi Ishimaru ${ }^{1}$ \\ ${ }^{1}$ Department of Ocean Sciences, Tokyo University of Fisheries, 4-5-7 Konan, Minato-ku, Tokyo 108-8477, Japan \\ ${ }^{2}$ Present address: Louisiana Universities Marine Consortium, 8124 Highway 56, Chauvin, Louisiana 70344, USA
}

\begin{abstract}
Appendicularians, pelagic tunicates that are common in world oceans, periodically produce new mucus houses and discard old ones. Discarded houses form macroscopic aggregates that constitute sites of biological activity in the water column and also contribute to the transport of organic matter to deeper water. In this study, we measured the house renewal rates of 10 appendicularian species cultivated in $30 \mu \mathrm{m}$-mesh-screened seawater at 17 to $29^{\circ} \mathrm{C}$. In addition, the carbon content of the tunicates $\left(\mathrm{C}_{\mathrm{B}}\right)$, their newly secreted houses $\left(\mathrm{C}_{\mathrm{NH}}\right)$ and their discarded houses $\left(\mathrm{C}_{\mathrm{DH}}\right)$ were concurrently examined for some of the oikopleurid species. House renewal rates varied from 2 houses $\mathrm{d}^{-1}$ for Oikopleura cophocerca at $20^{\circ} \mathrm{C}$ to 40 houses d $\mathrm{d}^{-1}$ for Fritillaria formica digitata at $23^{\circ} \mathrm{C}$. The $\mathrm{C}_{\mathrm{NH}}$ of $O$. longicauda, $O$. fusiformis, $O$. rufescens and Megalocercus huxleyi were $0.16,0.48,1.6$ and $8.8 \mu \mathrm{g}$, corresponding to $5.3,9.2,14.1$ and $10.3 \%$ of $\mathrm{C}_{\mathrm{B}}$, respectively; the $\mathrm{C}_{\mathrm{DH}}$ of the first 3 species were $0.68,1.2$ and $3.9 \mu \mathrm{g}$, corresponding to $17.9,30.0$ and $32.8 \%$ of $C_{B}$, respectively $\left(C_{D H}\right.$ was not measured in $M$. huxleyi). House renewal rates decreased with increasing $\mathrm{C}_{\mathrm{NH}} / \mathrm{C}_{\mathrm{B}}$ ratios for all species. Our calculations indicate that at $23^{\circ} \mathrm{C}$, populations of $O$. longicauda, O. fusiformis, O. rufescens and $M$. huxleyi produced new houses corresponding to $112,217,75$ and $89 \%$ of their biomass $\mathrm{d}^{-1}$, and that the first 3 species could discard houses corresponding to 380,708 and $174 \%$ of their biomass $\mathrm{d}^{-1}$, respectively. The individual lifetime production of $\mathrm{C}_{\mathrm{NH}}$ and $\mathrm{C}_{\mathrm{DH}}$ for all 3 species was estimated to be 1.1 to 3.6 and 2.7 to 12 times greater than the $C_{B}$ of mature individuals. This high houseproductivity, combined with large population sizes, indicates that appendicularians are major producers of macroscopic aggregates in marine ecosystems.
\end{abstract}

KEY WORDS: Appendicularians $\cdot$ House $\cdot$ House renewal rate $\cdot$ Carbon content $\cdot$ Macroscopic aggregates

\section{INTRODUCTION}

Appendicularians, which are common in marine zooplankton communities, live and feed within a complex mucus structure known as their 'house' (Lohmann 1909, Alldredge 1976a). With a sinusoidal tail movement, the appendicularian draws water into its house through coarse-meshed inlet filters which exclude particles that are too large to ingest. Inside the house, finemeshed filters sieve the food, collecting small particles such as nano- and pico-plankton which are concentrated and ingested. Some particles (comprising phytoplankton cells, ciliates, bacteria and fecal pellets of the occupying tunicate) accumulate in the house without being ingested (Alldredge 1972, 1976a,b, Davoll \& Silver 1986, Gorsky \& Palazzoli 1989, Bedo et al. 1993, Hansen et al. 1996, Bochdansky et al. 1998). Houses are periodically discarded. Discarded houses are a complex of mucus, particles retained inside the house and particles attached to the outside of the house. A new house is immediately built. Each individual repeats this process 2 to 19 times per day (Flood \& Deibel 1998, Sato et al. 2001), and appendicularians have thus been considered important producers of macroscopic aggregates (Alldredge 1976b, 1979, Silver \& Alldredge 1981, Taguchi 1982, Alldredge \& Gotschalk 1990, Hamner \& Robison 1992, Hansen et al. 1996, Sato et al. 2001). There are, however, few quantitative measurements of 
house renewal rate (see review by Flood \& Deibel 1998). Some measurements of house carbon content have been made for Oikopleura cornutogastra, O. fusiformis, O. intermedia, O. longicauda, O. rufescens, O. vanhoeffeni, Megalocercus huxleyi and Stegosoma magnum (Alldredge 1976b, 1979, Taguchi 1982, Deibel 1986, Riehl 1992 in Flood \& Deibel 1998). Most of these measurements, however, were for discarded houses (houses and associated particles). The carbon content of newly secreted, particle-free houses (the amount of carbon invested to build the house) has been reported only for O. rufescens (Alldredge 1976b), O. vanhoeffeni (Deibel 1986, Riehl 1992 in Flood \& Deibel 1998) and O. dioica (Sato et al. 2001).

In the present study, house renewal rates for $10 \mathrm{ap}-$ pendicularian species were measured. These 10 species included members of all 3 families of Appendicularia (Oikopleuridae, Fritillariidae and Kowalevskiidae). In addition, we measured the carbon contents of some oikopleurids, their newly secreted houses, and their discarded houses. These data allowed us to determine the importance of these appendicularians as producers of macroscopic aggregates.

\section{MATERIALS AND METHODS}

Live individuals were collected from surface waters 100 to $300 \mathrm{~m}$ off the Banda Marine Laboratory, Tokyo University of Fisheries, Japan. They were collected individually, together with their houses, in $300 \mathrm{ml}$ transparent plastic vessels by a diver and brought to the laboratory immediately. They were sorted by species into 3 or 51 plastic beakers filled with ambient seawater screened through $30 \mu \mathrm{m}$-mesh netting. These appendicularians were kept as stock cultures using apparatus especially designed for their cultivation through several generations (Sato et al. 1999). For all experiments, chlorophyll a concentration was determined by filtering $200 \mathrm{ml}$ of $30 \mu \mathrm{m}$-mesh-screened seawater through a Whatman GF/F glass-fiber filter. These samples were extracted in $6 \mathrm{ml}$ of $\mathrm{N}, \mathrm{N}$-dimethylformamide, and chlorophyll a concentrations were measured fluorometrically with a Turner design fluorometer (Suzuki \& Ishimaru 1990).

Determination of house renewal rates. Individual Oikopleura rufescens were placed in $300 \mathrm{ml}$ plastic beakers filled with seawater screened through $30 \mu \mathrm{m}$ mesh. Beakers were then set on a motor-driven rotating table of $50 \mathrm{~cm}$ diameter to gently mix the water, in order to keep tunicates suspended (Sato et al. 2001). Individuals were transferred to new beakers containing fresh food medium every $4 \mathrm{~h}$ by use of a wide-bore pipette or a transferring apparatus (Sato et al. 1999). Discarded houses in the old beakers were counted.
Experiments were terminated by removing individuals from the beakers after $12 \mathrm{~h}$. The experiments were conducted under $5 \mu \mathrm{E} \mathrm{m} \mathrm{m}^{-2} \mathrm{~s}^{-1}$ irradiance at 20, 23 and $26^{\circ} \mathrm{C}$, adjusted by setting the rotating table in a temperature-controlled chamber.

Other appendicularian species were so sensitive that contact of their houses with the inside walls of the small beakers caused them to prematurely discard their houses. To reduce this problem, individuals were individually (4 to 5 animals for Oikopleura longicauda) maintained in larger, 3 or 5 l, plastic beakers filled with seawater screened through a $30 \mu \mathrm{m}$ mesh. The beakers were maintained on the cultivating apparatus of Sato et al. (1999). Experimental conditions such as water temperature, irradiance, feeding period and transfer interval were identical to those in the experiments using the rotating table, except that additional temperatures of 17 and $29^{\circ} \mathrm{C}$ were used for $O$. longicauda. Even under these conditions, O. longicauda, O. fusiformis, Fritillaria formica digitata and Kowalevskia tenuis sometimes escaped from the house while being transferred to new beakers. Experiments with these species were thus terminated after $6 \mathrm{~h}$ in the same beaker.

Determination of house carbon content. The carbon contents of both newly secreted, particle-free houses $\left(\mathrm{C}_{\mathrm{NH}}\right)$ and discarded houses with associated particles $\left(\mathrm{C}_{\mathrm{DH}}\right)$ were measured for Oikopleura longicauda, O. fusiformis and O. rufescens. For Megalocercus huxleyi, only $\mathrm{C}_{\mathrm{NH}}$ was determined. Body carbon content $\left(C_{B}\right)$ was also determined to obtain the ratios of $\mathrm{C}_{\mathrm{NH}} / \mathrm{C}_{\mathrm{B}}$ and $\mathrm{C}_{\mathrm{DH}} / \mathrm{C}_{\mathrm{B}}$.

$\boldsymbol{C}_{\boldsymbol{N}}$ determination: We used the method described in Sato et al. (2001). Similar-sized individuals of each species were prodded, forcing them to abandon their old houses. While expanding their new houses, the tunicates were transferred to membrane-filtered (0.2 $\mu \mathrm{m}$ pore size) seawater to prevent particles from adhering to the houses. Because particle-free houses are almost completely transparent, the tunicates were then transferred to membrane-filtered seawater to which we added powder of a pre-ashed $\left(480^{\circ} \mathrm{C}\right.$ for $\left.3 \mathrm{~h}\right)$ GF/C filter; the powder was taken up by the mucus and thus made the house visible. We then forced the animals to leave their houses by transferring them to a $3 \% \mathrm{KCl}$ solution. Organisms and houses were separately pipetted onto pre-ashed $24 \mathrm{~mm} \mathrm{GF/C} \mathrm{filters} \mathrm{and}$ dried at $60^{\circ} \mathrm{C}$ for $24 \mathrm{~h}$. The number of organisms and houses on each filter ranged from 1-2 for Megalocercus huxleyi to 25-30 for Oikopleura longicauda. The carbon contents of these samples were determined using a Yanagimoto MT-3 CHN analyzer.

$\boldsymbol{C}_{D H}$ determination: Oikopleura fusiformis and $O$. rufescens were individually sorted into $300 \mathrm{ml}$ plastic beakers filled with screened seawater and maintained on the rotating table. After several hours, 7 to 15 indi- 
viduals were removed from the beakers, forced to abandon their houses by immersion in $3 \% \mathrm{KCl}$ solution, pipetted onto pre-ashed GF/C filters and dried. The discarded houses in the beakers were also removed, pipetted onto pre-ashed GF/C filters and dried.

Oikopleura longicauda houses are smaller than those of O. fusiformis and O. rufescens (Alldredge 1977), and therefore a larger number of their houses was required for quantitative measurements. However, simultaneous collection of large numbers of both discarded houses and occupants was difficult. Instead, we derived relationships between fecal pellet length and body size (trunk length), and between trunk length and $\mathrm{C}_{\mathrm{B}}$, and used these to estimate $C_{B}$ from fecal pellet length. Laboratory observations showed that $70 \%$ of the discarded houses of Oikopleura longicauda contained fecal pellets. To develop these relationships, we used 20 similar-sized $O$. longicauda, cultivated in 51 beakers filled with screened seawater. Discarded houses were collected from the beakers. After microscopic measurement of the length of the major axis of the fecal pellets within the discarded houses, 30 to 50 of these houses were pipetted onto pre-ashed GF/C filters. The carbon content of these samples was determined using the method described above.

Estimation of daily house production. For Oikopleura longicauda, O. fusiformis, O. rufescens and Megalocercus huxleyi, the ratio of daily new house production to appendicularian biomass was calculated by multiplying the ratio of $\mathrm{C}_{\mathrm{NH}} / \mathrm{C}_{\mathrm{B}}$ and the house renewal rate. Similarly, the ratio of daily discarded house production to appendicularian biomass was calculated for each species using the $\mathrm{C}_{\mathrm{DH}} / \mathrm{C}_{\mathrm{B}}$ ratio of each.

Estimation of lifetime house production. We also estimated the total number of houses and total amount of house carbon produced by an individual during its lifetime for Oikopleura longicauda, O. fusiformis and $O$. rufescens. The procedures are briefly described below (see Sato et al. 1999 for the cultivation method and Sato et al. 2001 for details of the estimation of house number and carbon content). Fertilized eggs were kept in 3 or 51 beakers filled with $30 \mu \mathrm{m}$-meshscreened seawater using the cultivating apparatus at 20,23 and $26^{\circ} \mathrm{C}$ (plus 17 and $29^{\circ} \mathrm{C}$ for O. longicauda). After hatching, individuals were transferred to a fresh beaker 1 to 3 times per day. Every 1 to $3 \mathrm{~d}$ after fertilization, 5 to 20 individuals were sampled and fixed in $5 \%$ buffered formaldehyde seawater solution, and their trunk length (including gonad) was measured immediately under a microscope. Tail length was concurrently measured to obtain the tail-trunk length regression of each species. This allowed conversion of tail length to trunk length when gonads of mature individuals ruptured on fixation. The $\mathrm{C}_{\mathrm{B}}$ of varioussized individuals of these 3 species were determined to obtain the trunk length $-C_{B}$ regression for each species. After measurement of trunk length, 1 to 30 individuals of similar size for each species were transferred onto pre-ashed GF/C filters and dried, and their carbon content was analyzed using the method described above. For each species, trunk length was converted to the $\mathrm{C}_{\mathrm{B}}$ using the appropriate regression. The temporal change $\left(C_{t}\right)$ of $C_{B}$ for each species at each temperature was fit by the logistic curve expressed as:

$$
C_{t}=C_{\infty} /\left(1+\mathrm{e}^{a-b t}\right)
$$

where $C_{t}$ is the $\mathrm{C}_{\mathrm{B}}$ at $t$ hours after fertilization, $C_{\infty}$ is the maximum $\mathrm{C}_{\mathrm{B}}$ theoretically reached, and $a$ and $b$ are specific constants. The period from fertilization to expansion of a specified number of houses ( $t_{\mathrm{n}}$, hours) was calculated from:

$$
t_{\mathrm{n}}=t_{1}+t_{\mathrm{h}}(\mathrm{n}-1)
$$

where $t_{1}$ is the period from fertilization to expansion of the first house and $t_{\mathrm{h}}$ is the house renewal interval, which is equal to the reciprocal of house renewal rate. We assumed that the house renewal rates of these 3 species would be constant through their lifetimes regardless of body size, food concentration or light condition (Sato et al. 2001). The total number of houses produced by an individual during its lifetime can be calculated by inserting the generation time into $t_{\mathrm{n}}$ of Eq. (2). Given the total house number $m$, the total house carbon $\left(C_{\mathrm{TH}}\right)$ produced by an individual during its lifetime can be calculated by combining (1) and (2) into:

$$
C_{\mathrm{TH}}=\sum_{i=t_{1}}^{t_{\mathrm{m}}} C_{i} \times r
$$

where $r$ is the ratio $\mathrm{C}_{\mathrm{NH}} / \mathrm{C}_{\mathrm{B}}$ or $\mathrm{C}_{\mathrm{DH}} / \mathrm{C}_{\mathrm{B}}$.

\section{RESULTS}

\section{House renewal rate}

The mean house renewal rates varied considerably among species, ranging from 2 houses $\mathrm{d}^{-1}$ for Oikopleura cophocerca to 40 houses $\mathrm{d}^{-1}$ for Fritillaria formica digitata (Table 1). House renewal rates tended to increase with increasing temperature.

\section{House carbon content}

The $\mathrm{C}_{\mathrm{NH}}$ ranged from $0.16 \mu \mathrm{g}$ for Oikopleura longicauda, the smallest of the 4 species examined, to $8.8 \pm$ $2.2 \mu \mathrm{g}$ (mean $\pm \mathrm{SD}$ ) for Megalocercus huxleyi, the largest species examined (Table 2). The ratios of $\mathrm{C}_{\mathrm{NH}} / \mathrm{C}_{\mathrm{B}}$ ranged from $5.7 \%$ for $O$. longicauda to $16.5 \pm$ 
Table 1. House renewal rates, $H$ (means $\pm \mathrm{SD}$ ), of appendicularian species at various temperatures. n: no. of individuals examined; nd: no data

\begin{tabular}{|c|c|c|c|c|}
\hline Species & $T\left({ }^{\circ} \mathrm{C}\right)$ & Chl a $\left(\mu g \mathrm{l}^{-1}\right)$ & $H\left(\right.$ houses $\mathrm{d}^{-1}$ ) & $\mathrm{n}$ \\
\hline \multicolumn{5}{|l|}{ Oikopleuridae } \\
\hline \multirow{5}{*}{ Oikopleura longicauda } & 17 & $0.5-0.7$ & $13.4 \pm 1.0$ & 20 \\
\hline & 20 & $1.4-1.5$ & $15.6 \pm 0.8$ & 20 \\
\hline & 23 & $1.0-2.0$ & $21.2 \pm 1.9$ & 20 \\
\hline & 26 & $0.6-0.9$ & $23.6 \pm 1.0$ & 20 \\
\hline & 29 & 0.3 & 24 & 8 \\
\hline \multirow[t]{3}{*}{ O. fusiformis } & 20 & $0.4-0.8$ & $18.4 \pm 2.2$ & 9 \\
\hline & 23 & $0.4-1.2$ & $23.6 \pm 2.4$ & 9 \\
\hline & 26 & $0.3-0.4$ & $27.3 \pm 3.5$ & 11 \\
\hline \multirow[t]{3}{*}{ O. rufescens } & 20 & 0.7 & $3.5 \pm 0.9$ & 8 \\
\hline & 23 & $0.2-0.3$ & $5.3 \pm 1.0$ & 17 \\
\hline & 26 & $0.4-0.6$ & $5.2 \pm 1.0$ & 28 \\
\hline O. cophocerca & 20 & nd & 2 & 1 \\
\hline O. cornutogastra & 23 & 0.3 & 20 & 1 \\
\hline \multirow{2}{*}{ O. intermedia } & 20 & 0.6 & 8 & 1 \\
\hline & 23 & 0.4 & 8 & 1 \\
\hline \multirow{2}{*}{ Megalocercus huxleyi } & 20 & 0.7 & $6.0 \pm 1.6$ & 4 \\
\hline & 23 & $0.2-0.6$ & $8.6 \pm 0.9$ & 5 \\
\hline Stegosoma magnum & 23 & $0.2-0.6$ & 8 & 2 \\
\hline \multicolumn{5}{|l|}{ Fritillaridae } \\
\hline Fritillaria formica digitata & 23 & 0.8 & 40 & 2 \\
\hline \multicolumn{5}{|l|}{ Kowalevskiidae } \\
\hline Kowalevskia tenuis & 20 & 0.2 & 6 & 2 \\
\hline
\end{tabular}

$3.8 \%$ for O. rufescens. Individuals in this experiment discarded old and new houses consecutively, so $\mathrm{C}_{\mathrm{B}}$ did not include carbon of the house rudiment (which is secreted and attached to the tunicates' trunk while they still occupy their old houses; Alldredge 1976a). To estimate life-time house production using Eqs. (1), (3) and (5) to (7) (see later subsection), we used the $C_{B}$ of individuals that included the house rudiment, thus recalculating the $\mathrm{C}_{\mathrm{NH}} / \mathrm{C}_{\mathrm{B}}$ ratios under the assumption that the carbon content of the rudiment was equivalent to $\mathrm{C}_{\mathrm{NH}}$; we thereby obtained corrected $\mathrm{C}_{\mathrm{NH}} / \mathrm{C}_{\mathrm{B}}\left(=\mathrm{C}_{\mathrm{NH}} /\left[\mathrm{C}_{\mathrm{B}}+\mathrm{C}_{\mathrm{NH}}\right]\right)$ ratios ranging from 5.3 to $14.1 \%$ (Table 2).

The $\mathrm{C}_{\mathrm{DH}}$ values $(0.68 \pm 0.15 \mu \mathrm{g}$ for Oikopleura longicauda, $1.2 \pm 0.26 \mu \mathrm{g}$ for $O$. fusiformis and $3.9 \pm 1.1 \mu \mathrm{g}$ for $O$. rufescens: Table 3) were higher than the $\mathrm{C}_{\mathrm{NH}}$ values (Table 2). The relationship between fecal pellet length $\left(L_{\mathrm{F}} ; \mu \mathrm{m}\right)$ and trunk length $\left(L_{\mathrm{TR}} ; \mu \mathrm{m}\right)$ of $O$. longicauda was expressed as:

$$
\begin{gathered}
L_{\mathrm{TR}}=3.15 \times L_{\mathrm{F}}+109 \\
\left(\mathrm{r}^{2}=0.868, \mathrm{n}=55, \mathrm{p}<0.001\right)
\end{gathered}
$$

Using this regression and the trunk length- $\mathrm{C}_{\mathrm{B}}$ regression (see subsection 'Lifetime house production'), we obtained the $\mathrm{C}_{\mathrm{B}}$ of $O$. longicauda individuals which had discarded their houses. The ratios of $\mathrm{C}_{\mathrm{DH}} / \mathrm{C}_{\mathrm{B}}$ were $17.9 \pm 8.4 \%$ for $O$. longicauda, $30.0 \pm 6.6 \%$ for $O$. fusiformis and $32.8 \pm 4.4 \%$ for O. rufescens (Table 3 ), equivalent to $3.4,3.3$ and 2.3 times the $\mathrm{C}_{\mathrm{NH}} / \mathrm{C}_{\mathrm{B}}$ ratios, respectively.

\section{Daily house production}

On a carbon basis, daily new house production by Oikopleura longicauda corresponded to $71-127 \%$ of the organism biomass, and daily discarded house production corresponded to $240-430 \%$ of the biomass at 17 to $29^{\circ} \mathrm{C}$ (Table 4 ). The daily new and discarded house production by $O$. rufescens corresponded to

Table 2. Oikopleura spp. and Megalocercus huxleyi. Carbon content (means $\pm \mathrm{SD}$ ) of newly secreted, particle-free house $\left(\mathrm{C}_{\mathrm{NH}}\right)$. Since organisms discarded 2 houses successively in this experiment, corrected ratios $(P)$ of $\mathrm{C}_{\mathrm{NH}} / \mathrm{C}_{\mathrm{B}}$ (body carbon) were calculated

\begin{tabular}{|c|c|c|c|c|c|}
\hline Species & $\mathrm{C}_{\mathrm{B}}\left(\mu \mathrm{g}\right.$ ind $\left.^{-1}\right)$ & $\mathrm{C}_{\mathrm{NH}}\left(\mu \mathrm{g}\right.$ house $\left.^{-1}\right)$ & Ratio (\%) $\mathrm{C}_{\mathrm{NH}} / \mathrm{C}_{\mathrm{B}}$ & Corrected ratio $(P, \%)$ & $\mathrm{n}$ \\
\hline O. longicauda & 3.1 & 0.16 & 5.7 & 5.3 & 2 \\
\hline O. fusiformis & $4.7 \pm 0.3$ & $0.48 \pm 0.01$ & $10.2 \pm 0.8$ & $9.2 \pm 0.6$ & 3 \\
\hline O. rufescens & $10.4 \pm 4.0$ & $1.6 \pm 0.6$ & $16.5 \pm 3.8$ & $14.1 \pm 2.8$ & 7 \\
\hline M. huxleyi & $79.0 \pm 25.4$ & $8.8 \pm 2.2$ & $11.5 \pm 2.5$ & $10.3 \pm 2.0$ & 5 \\
\hline
\end{tabular}
as $P=100 \times \mathrm{C}_{\mathrm{NH}} /\left(\mathrm{C}_{\mathrm{NH}}+\mathrm{C}_{\mathrm{B}}\right)$, see 'Results'; n: no. of samples

Table 3. Oikopleura spp. Carbon content of discarded house $\left(\mathrm{C}_{\mathrm{DH}}\right)$. Also shown are chlorophyll a concentrations in water used for maintaining tunicates during collection of discarded houses. $\mathrm{C}_{\mathrm{B}}$ : body carbon; $\mathrm{n}$ : no. of samples

\begin{tabular}{|lcccc|}
\hline Species & $\mathrm{Chl}\left(\mu \mathrm{g} \mathrm{l}^{-1}\right)$ & $\mathrm{C}_{\mathrm{B}}\left(\mu \mathrm{g} \mathrm{ind}^{-1}\right)$ & $\mathrm{C}_{\mathrm{DH}}\left(\mu \mathrm{g}\right.$ house $\left.{ }^{-1}\right)$ & ${\text { Ratio }(\%) \mathrm{C}_{\mathrm{DH}} / \mathrm{C}_{\mathrm{B}}}^{\mathrm{n}}$ \\
\hline O. longicauda & $0.3-0.4$ & $4.3 \pm 1.9$ & $0.68 \pm 0.15$ & $17.9 \pm 8.4$ \\
O. fusiformis & 0.4 & $4.1 \pm 1.2$ & $1.2 \pm 0.26$ & $30.0 \pm 6.6$ \\
O. rufescens & $0.7-1.0$ & $11.8 \pm 2.3$ & $3.9 \pm 1.1$ & $32.8 \pm 4.4$ \\
\hline
\end{tabular}


Table 4. Oikopleura spp. and Megalocercus huxleyi. Ratio of daily new house production $\left(\mathrm{C}_{\mathrm{NHP}}\right)$ and daily discarded house production $\left(\mathrm{C}_{\mathrm{DHP}}\right)$ by appendicularians to their biomass $\left(\mathrm{C}_{\mathrm{Bio}}\right)$ (on carbon basis) at various temperatures. nd: no data

\begin{tabular}{|lcc|}
\hline Species & \multicolumn{3}{c|}{ Ratio (\%) } & \\
\cline { 2 - 3 }$\left({ }^{\circ} \mathrm{C}\right)$ & $\mathrm{C}_{\mathrm{NHP}} / \mathrm{C}_{\mathrm{Bio}}$ & $\mathrm{C}_{\mathrm{DHP}} / \mathrm{C}_{\mathrm{Bio}}$ \\
\hline O. longicauda & & \\
17 & 71 & 240 \\
20 & 83 & 279 \\
23 & 112 & 380 \\
26 & 125 & 422 \\
29 & 127 & 430 \\
O. fusiformis & & \\
20 & 169 & 552 \\
23 & 217 & 708 \\
26 & 251 & 819 \\
O. rufescens & & \\
20 & 49 & 115 \\
23 & 75 & 174 \\
26 & 73 & nd \\
M. huxleyi & & \\
20 & 62 & \\
23 & 89 & \\
\end{tabular}

$49-73 \%$ and $115-171 \%$ of the organism biomass at 20 to $26^{\circ} \mathrm{C}$, respectively. These values were lower than those for O. longicauda. For O. fusiformis, the daily production of new and discarded houses corresponded to $169-251 \%$ and $552-819 \%$ of the organism biomass, the highest production of the 4 species. Daily new house production by Megalocercus huxleyi corresponded to 62 and $89 \%$ of the organism biomass at 20 and $23^{\circ} \mathrm{C}$. These ratios increased with increasing tem- perature concordant with the increase in house renewal rates with increasing temperature (Table 1).

\section{Lifetime house production}

We determined the generation time as the period from fertilization until $>50 \%$ of the survivors became mature. The generation time of Oikopleura longicauda ranged from $4 \mathrm{~d}$ at 26 and $29^{\circ} \mathrm{C}$ to $10 \mathrm{~d}$ at 17 and $20^{\circ} \mathrm{C}$ (Table 5). Generation times were $3 \mathrm{~d}$ at $26^{\circ} \mathrm{C}$ and $4 \mathrm{~d}$ at $23^{\circ} \mathrm{C}$ for $O$. fusiformis, and $6 \mathrm{~d}$ at $26^{\circ} \mathrm{C}$ and $8 \mathrm{~d}$ at $23^{\circ} \mathrm{C}$ for O. rufescens (Table 5). At $20^{\circ} \mathrm{C}$, large individuals of $O$. fusiformis and O. rufescens could grow and spawn, but laboratory-hatched individuals of both species died within several days.

The trunk length of each species was converted to $\mathrm{C}_{\mathrm{B}}$, using trunk length $\left(L_{\mathrm{TR}} ; \mu \mathrm{m}\right)-\mathrm{C}_{\mathrm{B}}(\mu \mathrm{g})$ regression equations

$$
\begin{gathered}
\mathrm{C}_{\mathrm{B}}=3.29 \times 10^{-8} L_{\mathrm{TR}}^{2.85} \\
\left(\mathrm{r}^{2}=0.948, \mathrm{n}=21, \mathrm{p}<0.001\right) \text { for } \text { O. longicauda } \\
\mathrm{C}_{\mathrm{B}}=7.79 \times 10^{-9} L_{\mathrm{TR}}^{3.00} \\
\left(\mathrm{r}^{2}=0.989, \mathrm{n}=12, \mathrm{p}<0.001\right) \text { for } O \text {. fusiformis } \\
\mathrm{C}_{\mathrm{B}}=8.20 \times 10^{-8} L_{\mathrm{TR}}^{2.70} \\
\left(\mathrm{r}^{2}=0.923, \mathrm{n}=24, \mathrm{p}<0.001\right) \text { for O. rufescens }
\end{gathered}
$$

and was fit by logistic curves as shown in Figs. 1 to 3. After the first day of spawning, mean $\mathrm{C}_{\mathrm{B}}$ sometimes appeared to decrease because several large individuals had already spawned before the sampling time and their fragile tails were damaged by struggling or being trapped on the water surface, resulting in the lack of

\begin{tabular}{|c|c|c|c|c|c|c|c|c|}
\hline $\begin{array}{l}\text { Species } \\
T\left({ }^{\circ} \mathrm{C}\right)\end{array}$ & $\begin{array}{l}\text { Period } \\
\text { (h) }\end{array}$ & $\begin{array}{l}\text { Gen time } \\
\text { (d) }\end{array}$ & $\mathrm{mC}_{\mathrm{B}}$ & $\begin{array}{c}\text { Total } \\
\text { houses }\end{array}$ & $\begin{array}{l}\text { Total } \\
\mathrm{C}_{\mathrm{NH}}\end{array}$ & $\begin{array}{l}\text { Total } \\
\mathrm{C}_{\mathrm{DH}}\end{array}$ & $\begin{array}{c}\text { Total } \\
\mathrm{C}_{\mathrm{NH}} / \mathrm{mC}_{\mathrm{B}}\end{array}$ & $\begin{array}{c}\text { Total } \\
\mathrm{C}_{\mathrm{DH}} / \mathrm{mC}_{\mathrm{B}}\end{array}$ \\
\hline \multicolumn{9}{|c|}{ O. longicauda } \\
\hline 17 & 14 & 10 & $8.5 \pm 3.3$ & $127 \pm 10$ & 21.4 & 72.3 & 2.5 & 8.5 \\
\hline 20 & 12 & 10 & $7.3 \pm 2.3$ & $149 \pm 8$ & 16.2 & 54.8 & 2.2 & 7.5 \\
\hline 23 & 10 & 7 & $6.4 \pm 3.4$ & $141 \pm 13$ & 22.9 & 77.3 & 3.6 & 12.0 \\
\hline 26 & 7.5 & 4 & $2.3 \pm 1.0$ & $88 \pm 4$ & 4.1 & 13.8 & 1.8 & 6.1 \\
\hline 29 & 5 & 4 & $2.1 \pm 0.4$ & 92 & 6.4 & 21.4 & 3.1 & 10.4 \\
\hline \multicolumn{9}{|c|}{ O. fusiformis } \\
\hline 23 & 9 & 4 & $3.5 \pm 1.6$ & $86 \pm 9$ & 7.7 & 25.0 & 2.2 & 7.2 \\
\hline 26 & 7.5 & 3 & $5.6 \pm 0.8$ & $74 \pm 9$ & 8.8 & 28.8 & 1.6 & 5.1 \\
\hline \multicolumn{9}{|c|}{ O. rufescens } \\
\hline 23 & 14 & 8 & $13.0 \pm 4.2$ & $40 \pm 7$ & 21.4 & 49.7 & 1.6 & 3.8 \\
\hline 26 & 12 & 6 & $11.5 \pm 5.2$ & $30 \pm 6$ & 13.2 & 30.7 & 1.1 & 2.7 \\
\hline
\end{tabular}

Table 5. Oikopleura spp. Total number and carbon content of newly secreted and discarded houses produced by different appendicularian species during their lifetime at various temperatures. Period (h): period from fertilization to first house expansion; Gen time (d): generation time; $\mathrm{mC}_{\mathrm{B}}$ : body carbon of mature individual, i.e. body carbon of individual at generation time $($ mean $\pm \mathrm{SD}, \mu \mathrm{g})$; Total houses: total no. of houses (mean $\pm \mathrm{SD}$ houses ind. $\left.{ }^{-1}\right)$; Total $\mathrm{C}_{\mathrm{NH}}$, Total $\mathrm{C}_{\mathrm{DH}}$ : total amount of carbon in new and old houses, respectively ( $\mu \mathrm{g}$ ind.$^{-1}$ ) 


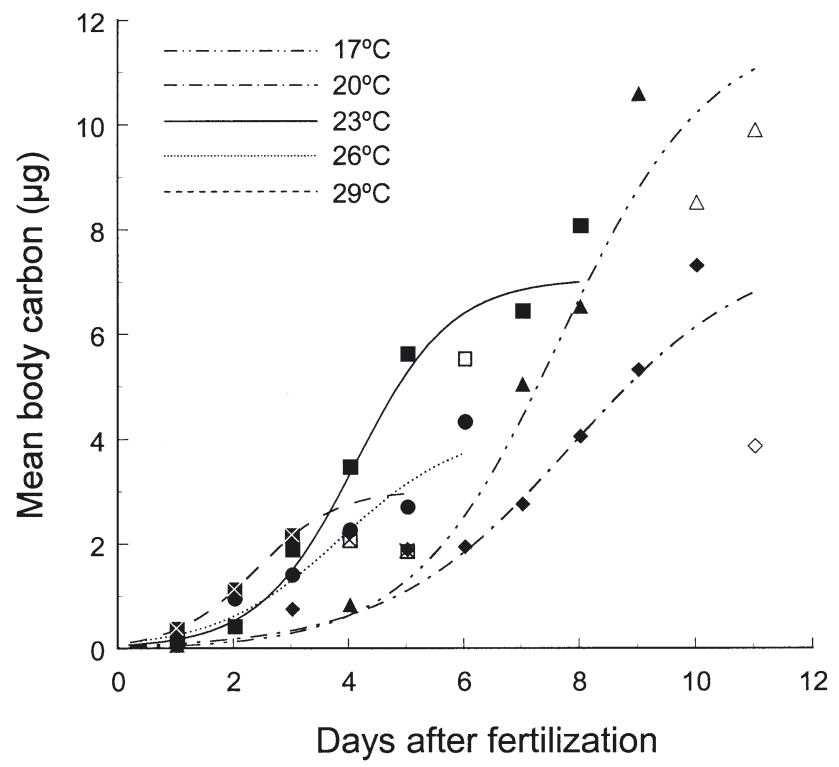

Fig. 1. Oikopleura longicauda. Growth as mean body carbon at $17^{\circ} \mathrm{C}(\boldsymbol{\Delta}, \Delta), 20^{\circ} \mathrm{C}(\bullet, \diamond), 23^{\circ} \mathrm{C}(\bullet, \square), 26^{\circ} \mathrm{C}(\bullet)$ and $29^{\circ} \mathrm{C}(\boldsymbol{\otimes}, \boldsymbol{\otimes})$. Lines are logistic curves fit to growth at each temperature; open symbols represent data excluded for purpose of fitting the curves. Equations of logistic curves for 17, 20,23, 26 and $29^{\circ} \mathrm{C}$ are: $C_{t}=11.9 /\left(1+\mathrm{e}^{5.97-0.778 t}\right), 7.77 /\left(1+\mathrm{e}^{4.90-0.624 t}\right)$, $7.05 /\left(1+\mathrm{e}^{4.94-1.20 t}\right), 4.23 /\left(1+\mathrm{e}^{3.63-0.945 t}\right)$ and $3.05 /\left(1+\mathrm{e}^{3.40-1.43 t}\right)$, respectively, where $C_{t}=$ body carbon at $t$ hours after fertilization. Chlorophyll a concentration in cultivation water $=0.5$ to $0.7,0.3$ to $0.7,0.4$ to $1.4,0.3$ to 0.8 and 0.3 to $0.5 \mu \mathrm{g} \mathrm{l}^{-1}$ for 17 , $20,23,26$ and $29^{\circ} \mathrm{C}$ respectively

tail length measurements. Therefore, the mean trunk length or $\mathrm{C}_{\mathrm{B}}$ will be slightly underestimated in these cases. If the temporal changes of $\mathrm{C}_{\mathrm{B}}$ are fit by logistic curves at this stage, the curves will deviate below the mean $C_{B}$. To fit the curve, we thus excluded the decreased $C_{B}$ data (open symbols in Figs. 1 to 3). The resultant growth curves provided a good description of the temporal changes in $C_{B}$ (Figs. 1 to 3 ) and could thus be used in Eq. (3). The total house number produced by an individual during its lifetime varied as a function of species and temperature, ranging from 88 to 149 for Oikopleura longicauda, 74 to 86 for $O$. fusiformis and 30 to 40 for $O$. rufescens (Table 5). Total $\mathrm{C}_{\mathrm{NH}}$ and total $\mathrm{C}_{\mathrm{DH}}$ ranged from 4.1 to $22.9 \mu \mathrm{g}$ and 13.8 to $77.3 \mu \mathrm{g}$ for O. longicauda, 7.7 to $8.8 \mu \mathrm{g}$ and 25.0 to $28.8 \mu \mathrm{g}$ for O. fusiformis, and 13.2 to $21.4 \mu \mathrm{g}$ and 30.7 to $49.7 \mu \mathrm{g}$ for O. rufescens, respectively. At temperatures exceeding $26^{\circ} \mathrm{C}$, the total house number and total house carbon of $O$. longicauda decreased abruptly, possibly due to the shorter generation time and smaller body size at higher temperatures (Fig. 1). The total $\mathrm{C}_{\mathrm{NH}}$ and total $\mathrm{C}_{\mathrm{DH}}$ were 1.1 to 3.6 and 2.7 to 12 times higher than the $\mathrm{C}_{\mathrm{B}}$ of mature individuals (Table 5 ).

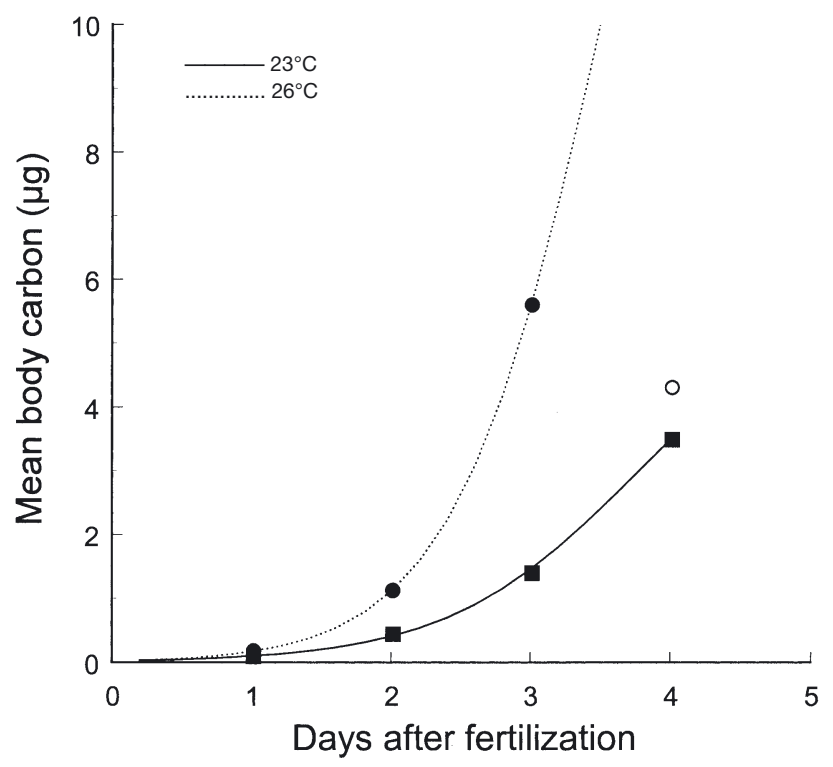

Fig. 2. Oikopleura fusiformis. Growth as mean body carbon at $23^{\circ} \mathrm{C}(\boldsymbol{\square})$ and $26^{\circ} \mathrm{C}(\bullet, \circ)$; open symbols as in Fig. 1. (At $23^{\circ} \mathrm{C}$, tunicates survived to Day 5, but were not sampled after Day 4.) Equations of logistic curves for 23 and $26^{\circ} \mathrm{C}$ are: $C_{t}=$ $5.96 /\left(1+\mathrm{e}^{5.58-1.48 t}\right)$ and $21.0 /\left(1+\mathrm{e}^{6.59-1.86 t}\right)$, respectively. Chlorophyll a concentrations in cultivation water were 0.4 to 1.2 and 0.3 to $1.2 \mu \mathrm{g} \mathrm{l}^{-1}$ for 23 and $26^{\circ} \mathrm{C}$, respectively

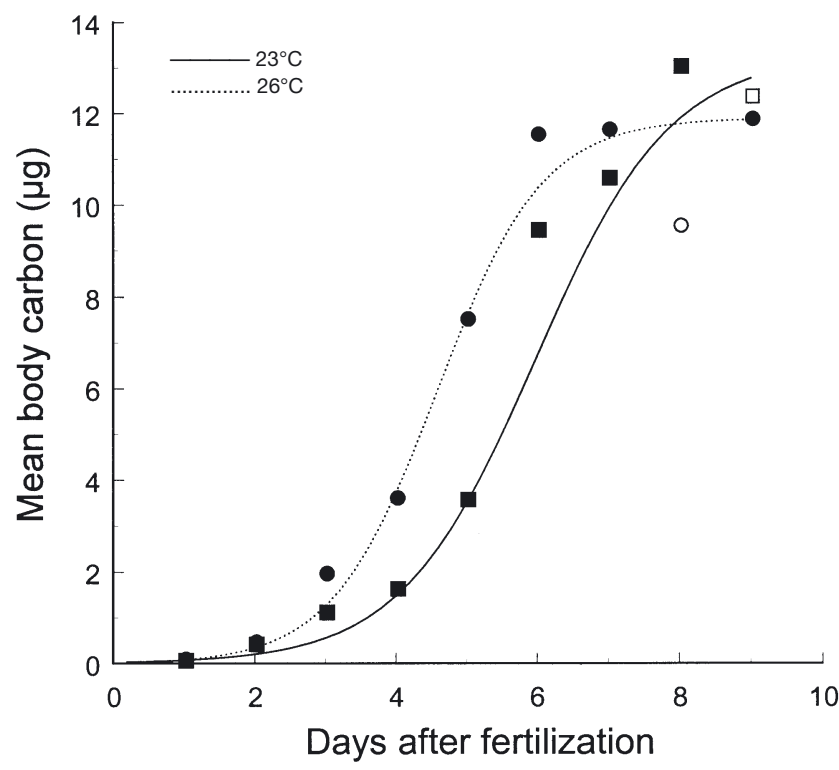

Fig. 3. Oikopleura rufescens. Growth as mean body carbon at $23^{\circ} \mathrm{C}\left(\bullet\right.$, 口) and $26^{\circ} \mathrm{C}(\bullet, 0)$; open symbols as in Fig. 1. Equations of logistic curves for 23 and $26^{\circ} \mathrm{C}$ are: $C_{t}=13.3$ / $\left(1+\mathrm{e}^{6.29-1.05 t}\right)$ and $11.9 /\left(1+\mathrm{e}^{6.13-1.34 t}\right)$, respectively. Chlorophyll a concentrations in cultivation water were 0.4 to 2.7 and 0.6 to $1.1 \mu \mathrm{g} \mathrm{l}^{-1}$ for 23 and $26^{\circ} \mathrm{C}$, respectively 


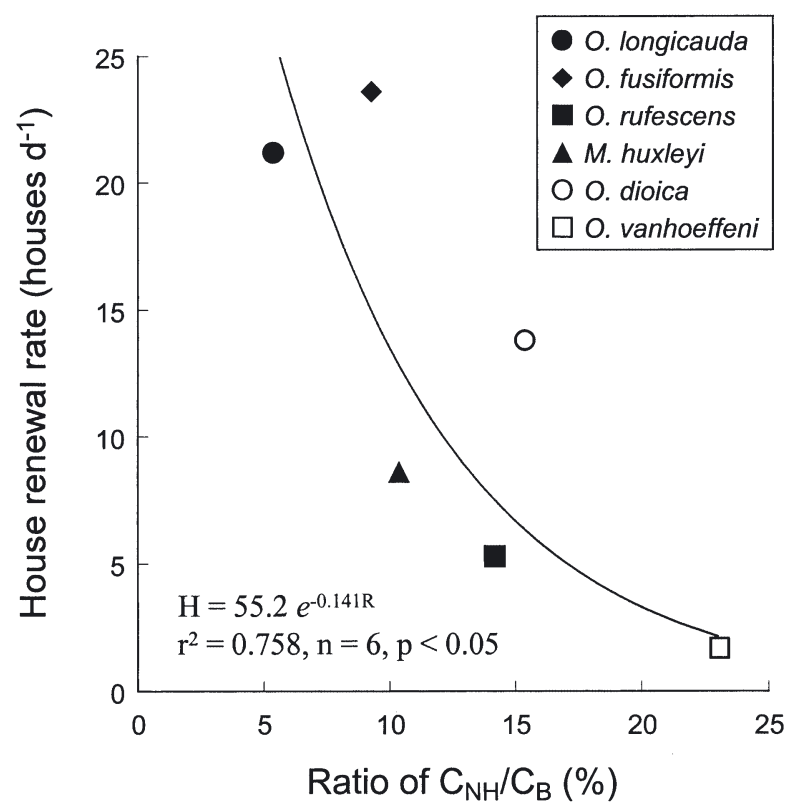

Fig. 4. Oikopleura spp. and Megalocercus huxleyi. Relationship between ratios of $\mathrm{C}_{\mathrm{NH}} / \mathrm{C}_{\mathrm{B}}(R, \mathrm{C}$ content of new house/C content of body) and house renewal rates $(H)$ at -0.6 to $5.8^{\circ} \mathrm{C}$ for $O$. vanhoeffeni and at $23^{\circ} \mathrm{C}$ for the other 5 species. For $O$. vanhoeffeni temperature and house renewal rates are from Riehl (1992, in Flood \& Deibel 1998) and $\mathrm{C}_{\mathrm{NH}} / \mathrm{C}_{\mathrm{B}}$ ratio from Deibel (1986); for O. dioica data are from Sato et al. (2001); for remaining species, data are from present study

\section{DISCUSSION}

In a previous study (Lohmann 1909), house renewal rate by Oikopleura rufescens was 6 houses $\mathrm{d}^{-1}$, similar the rate measured in our study. However, house renewal rates reported for Kowalevskia tenuis (Fol 1872) and O. longicauda (Taguchi 1982) were considerably different from our rates. Fol (1872) observed that $K$. tenuis built 1 house every $2 \mathrm{~h}$ when kept in a sufficiently large vessel. Taguchi (1982) obtained a house renewal rate of 5.3 houses $\mathrm{d}^{-1}$ for $O$. longicauda by using a complex calculation incorporating the abundance of discarded houses, tunicate abundance, losses due to sedimentation, and losses due to predation. Although we cannot find conclusive reasons for the considerable difference between these studies, we believe that our results reflect more natural values of house renewal rates since we reared these species in fairly good condition up to spawning for $K$. tenuis and through more than 10 filial generations for $O$. longicauda.

The $\mathrm{C}_{\mathrm{DH}}$ of each species obtained here was lower than that reported by Alldredge (1976b) or Taguchi (1982). These differences may be due to differences in the size of the houses collected and the quality and quantity of particles trapped on or in the houses.

\section{Relationship between house renewal rate and house carbon content}

House renewal rates varied between species. House renewal rate of Oikopleura rufescens was lower than in other species, except for O. cophocerca (Table 1). $O$. rufescens builds a small, highly gelatinous and firm house (Alldredge 1976b, 1977). The firmness of this house may result from a high $\mathrm{C}_{\mathrm{NH}} / \mathrm{C}_{\mathrm{B}}$ ratio and small house size. Among the 4 species examined, $O$. rufescens had the highest $\mathrm{C}_{\mathrm{NH}} / \mathrm{C}_{\mathrm{B}}$ ratio (Table 2). For $O$. cophocerca, low house renewal rate may result in a high $\mathrm{C}_{\mathrm{NH}} / \mathrm{C}_{\mathrm{B}}$ ratio. This presumption is supported by our observation that the houses of $O$. cophocerca were highly gelatinous and very firm.

In contrast, Oikopleura longicauda produced many houses per day with a low $\mathrm{C}_{\mathrm{NH}} / \mathrm{C}_{\mathrm{B}}$ ratio. This species is known to have no inlet filters. Except for large species such as $O$. vanhoeffeni, O. villafrancae or Megalocercus huxleyi, the mesh width of inlet filters is 13 to $35 \mu \mathrm{m}$ (Alldredge 1977, Fenaux 1986, Flood \& Deibel 1998). O. longicauda thus could draw particles $>35 \mu \mathrm{m}$ into its house, a particle size that is precluded by inlet filters in other species. According to Flood \& Deibel (1998), $100 \mu \mathrm{m}$ plastic beads were readily drawn into the house of $O$. longicauda, even by small individuals. This means that the food-concentrating filter would clog quickly with larger particles, and the organisms would have to build new houses more frequently. To produce many houses per day with a low $\mathrm{C}_{\mathrm{NH}} / \mathrm{C}_{\mathrm{B}}$ ratio may be advantageous for $O$. longicauda, as it allows more efficient filtration of food and energy investment for house synthesis relative to a high house renewal rate.

Oikopleura fusiformis builds a mucilaginous and fragile house (Alldredge 1976b, 1977), which seems to be so sticky that it can easily accumulate particles. In our experiments, of the total particles drawn into the house, the proportion that accumulated internally without being ingested was larger for $O$. fusiformis than for O. longicauda and O. rufescens (R. Sato et al. unpubl. data). Thus, this species would need to build new houses frequently, explaining its high house renewal rates. However, the $\mathrm{C}_{\mathrm{NH}} / \mathrm{C}_{\mathrm{B}}$ ratio of $O$. fusiformis was comparable to that of Megalocercus huxleyi, and house renewal rates of the former were about 3 times higher than that of the latter, resulting in a much higher carbon investment for house synthesis per unit time. Because carbon invested in house materials is supplied from ingested food, the difference in house productivity between the 2 species may derive from the difference in capacity of food collection or ingestion.

There was a relationship between the $\mathrm{C}_{\mathrm{NH}} / \mathrm{C}_{\mathrm{B}}$ ratio and the house renewal rate at $23^{\circ} \mathrm{C}$ for 6 species (Fig. 4). For Oikopleura dioica, house renewal rate at 
$23^{\circ} \mathrm{C}$ and 35 psu was calculated using relationships between house renewal rate and temperature and between house renewal rate and salinity (Sato et al. 2001). For O. vanhoeffeni, a large cold-water species, the house renewal rate of $1.7 \pm 0.78$ houses $\mathrm{d}^{-1}$ measured at temperatures between -0.6 and $+5.8^{\circ} \mathrm{C}$ (Riehl 1992 in Flood \& Deibel 1998), and the $\mathrm{C}_{\mathrm{NH}} / \mathrm{C}_{\mathrm{B}}$ ratio of $23 \%$ (Deibel 1986) are tentatively used in Fig. 4. The house renewal rate $\left(H_{\text {; }}\right.$ houses $\left.\mathrm{d}^{-1}\right)$ decreased exponentially with increasing $\mathrm{C}_{\mathrm{NH}} / \mathrm{C}_{\mathrm{B}}$ ratio $\left(R_{i} \%\right)$ (Fig. 4), expressed as

$$
\begin{gathered}
H=55.2 \mathrm{e}^{-0.141 R} \\
\left(\mathrm{r}^{2}=0.758, \mathrm{n}=6, \mathrm{p}<0.05\right)
\end{gathered}
$$

This suggests that the house renewal rates counterbalance $\mathrm{C}_{\mathrm{NH}} / \mathrm{C}_{\mathrm{B}}$ ratios, i.e. the carbon investment for each house. Species with lower carbon investment for each house have higher house renewal rates and vice versa.

\section{Importance of appendicularians as producers of macroscopic aggregates}

Clarke \& Roff (1990) and Hopcroft \& Roff (1998) estimated the house production (= new house production) by appendicularian communities in Jamaica, and suggested that annual house production could be about 10 to $40 \%$ of the annual production of the entire copepod community. In another study, Tomita et al. (1999) estimated the house production by Oikopleura longicauda populations in Toyama Bay, Japan, and showed that the annual house production of this species was much higher than the annual production by the euphausiid Euphausia pacifica, the most abundant zooplankton at the study site (Hirakawa et al. 1992). House production in Jamaica was calculated by applying rate data for $O$. dioica and $O$. rufescens to appendicularian communities that included various species (Clarke \& Roff 1990, Hopcroft \& Roff 1998), and in the Toyama Bay study, rate data for $O$. dioica were applied to O. longicauda populations. Because the house renewal rates and the $\mathrm{C}_{\mathrm{NH}} / \mathrm{C}_{\mathrm{B}}$ or $\mathrm{C}_{\mathrm{DH}} / \mathrm{C}_{\mathrm{B}}$ ratios vary considerably by species (Tables 1 to 3), the approach in these studies will have caused some errors. Nevertheless, these studies do indicate that house production by appendicularians comprises a considerable fraction of secondary production in marine ecosystems.

High house productivity by appendicularians is also shown by our results. The house renewal rates of Oikopleura dioica, a coastal species (Tokioka 1955, Fenaux et al. 1998), are regulated by temperature and salinity (Sato et al. 2001). In this study, the house renewal rates of many species were also affected by temperature (Table 1). For the species we examined (which are oceanic species: Tokioka 1955), variation in salinity may not be an important modifier of house renewal rates in situ. House production can be safely estimated from the abundance of the appendicularians and temperature in the field. For example, peak concentration of $O$. longicauda, often the dominant appendicularian species in warm oceanic waters (Tokioka 1940, 1960, Bückmann \& Kapp 1975, Fenaux et al. 1998), was 83 ind. $\mathrm{m}^{-3}$ in Suruga Bay, central Japan (Itoh 1990). Since water temperature was about $23^{\circ} \mathrm{C}$ at this time (Fig. 2 in Itoh 1990), the maximum number of discarded houses in Suruga Bay can be estimated as $1760 \mathrm{~m}^{-3} \mathrm{~d}^{-1}$ using the house renewal rate of 21.2 houses $\mathrm{d}^{-1}$ for each individual (Table 1). Taguchi (1982) found that the abundance of discarded houses of $O$. longicauda in Kaneohe Bay, Hawaii, reached $1.3 \times 10^{5}$ houses $\mathrm{m}^{-3}$. Discarded houses of $O$. longicauda could thus be an important source of macroscopic aggregates in the water column, depending on the abundance of these tunicates. Since O. fusiformis and $O$. rufescens are also distributed widely in warm oceanic waters (Tokioka 1940, 1960, Bückmann \& Kapp 1975, Fenaux et al. 1998), their discarded houses may also be a common component of macroscopic aggregates.

The daily new house production by Oikopleura longicauda, O. fusiformis, O. rufescens and Megalocercus huxleyi corresponded to between 50 and $250 \%$ of their biomass, and daily discarded house production corresponded to between 110 and $820 \%$ of the biomass (Table 4 ). These high rates indicate that appendicularians produce a large number of macroscopic aggregates in the form of houses. Furthermore, O. longicauda, O. rufescens and O. fusiformis invest 4 to $23 \mu \mathrm{g}$ of carbon in new house materials and release 14 to $77 \mu \mathrm{g}$ of carbon as discarded houses during their generation time of 3 to $10 \mathrm{~d}$ (Table 5). This is between 1.1 and 12 times the amount of carbon in a mature individual. This means that, on a carbon basis, house production by appendicularians can be much larger than somatic production. High productivity of macroscopic aggregates by appendicularians may be widely occurring events because of their ubiquitous distribution in the oceans.

The carbon content of a newly secreted house corresponds to $23 \%$ of $\mathrm{C}_{\mathrm{B}}$ for Oikopleura vanhoeffeni (Deibel 1986), $15.3 \%$ of $C_{B}$ for O. dioica (Sato et al. 2001) and 10 to $20 \%$ of ash-free dry weight for O. rufescens (Alldredge $1976 \mathrm{c}$ ). These data and our $\mathrm{C}_{\mathrm{NH}} / \mathrm{C}_{\mathrm{B}}$ values in this paper indicate that the houses contained a high proportion of the total carbon produced by the appendicularians. Moreover, discarded houses (Table 3) contained much more carbon than newly secreted ones (Table 2) because of adhering particles. Contrary to our results, however, Alldredge (1976b) reported that 
the carbon content of newly secreted, particle-free houses of $O$. rufescens was higher than that of fieldcollected discarded houses. As reported by Sato et al. (2001), houses collected in the field may have been discarded for some length of time before collection, allowing decomposition of house materials and reduction of carbon content to be advanced by the activity of microorganisms attached to the houses. Thus, it is likely that the carbon content of houses will continuously increase while they are occupied and decrease after they are discarded. Although newly secreted, particle-free houses contain very low or undetectable amounts of nitrogen (Alldredge 1976b, Riehl 1992 in Flood \& Deibel 1998), accumulation of phytoplankton, detritus and fecal materials in the house also enriches them with nitrogen (Alldredge 1976b). Discarded houses are therefore potentially valuable to other organisms. Various organisms such as bacteria (Alldredge \& Youngbluth 1985, Davoll \& Silver 1986, Davoll \& Youngbluth 1990), ciliates (Caron et al. 1986, Davoll \& Silver 1986), planktonic crustaceans (Alldredge 1972, 1976a,b, Ohtsuka \& Kubo 1991, Ohtsuka et al. 1993, 1996, Steinberg \& Silver 1994, Steinberg 1995) or anguilloid larvae (Mochioka \& Iwamizu 1996) are known to utilize discarded appendicularian houses.

Daily new house and discarded house production by Oikopleura dioica corresponds to $130-290 \%$ and $490-1100 \%$ of the animal biomass, respectively (Sato et al. 2001). In the present study, daily house production by $O$. fusiformis was comparable to that of $O$. dioica, but that by $O$. longicauda, O. rufescens and Megalocercus huxleyi was lower. The high abundance of $O$. dioica, sometimes exceeding $1 \times 10^{4}$ ind. $\mathrm{m}^{-3}$ (Seki 1973, Paffenhöfer 1976, Anakubo \& Murano 1991, Uye \& Ichino 1995, Nakamura et al. 1997, Nakamura 1998), is only occasionally recorded for oceanic larvacean species (Alldredge 1982, Hopcroft \& Roff 1998). The abundance and biomass of appendicularians thus appear to be generally lower in oceanic than coastal waters, and therefore house productivity in oceanic waters will generally be lower than that in coastal waters. Ohtsuka et al. (1993), however, observed the attachment of copepods to appendicularian houses in oceanic waters dominated by oceanic species, but not in coastal waters dominated by $O$. dioica. This suggests that the discarded houses are more important as a food source for copepods (and perhaps also for other organisms) in oligotrophic oceanic waters than in eutrophic coastal waters. Appendicularian assemblages in oceanic waters may be more important in aggregate food webs even though their total production is smaller.

Discarded houses sink at a rate of 26 to $189 \mathrm{~m} \mathrm{~d}^{-1}$ (Silver \& Alldredge 1981, Taguchi 1982, Gorsky et al. 1984, Hansen et al. 1996), except for the discarded houses of the giant appendicularian Bathochordaeus sp., which sink at a rate of $818 \pm 199 \mathrm{~m} \mathrm{~d}^{-1}$ (Hamner \& Robison 1992). The species examined here are found primarily in the upper $100 \mathrm{~m}$ of the water column (Tomita 1998), so sinking houses can potentially contribute to the transport of organic matter synthesized in the euphotic zone to deeper, less productive waters. However, as stated earlier, particulate organic matter contained in the discarded houses decreases over time and therefore would decrease while sinking through the water column. Therefore, the amount of organic matter actually transported to deeper water by the sinking of discarded houses will be smaller than the discarded house production estimated in this study.

Acknowledgements. We thank M. J. Dagg and G. Hanrahan, Louisiana Universities Marine Consortium, for critical reading of the manuscript. We are grateful for laboratory and field cooperation by Y. Koike and the staff of Banda Marine Laboratory. This work was supported by a grant from the Mikimoto Fund for Marine Ecology and by grant number NASA/LEQSF (2001-04)-02 to M. J. Dagg.

\section{LITERATURE CITED}

Alldredge AL (1972) Abandoned larvacean houses: a unique food source in the pelagic environment. Science 177: $885-887$

Alldredge AL (1976a) Appendicularians. Sci Am 235:95-102

Alldredge AL (1976b) Discarded appendicularian houses as sources of food, surface habitats, and particulate organic matter in planktonic environments. Limnol Oceanogr 21: $14-23$

Alldredge AL (1976c) Field behavior and adaptive strategies of appendicularians (Cordata: Tunicata). Mar Biol 38: 29-39

Alldredge AL (1977) House morphology and mechanisms of feeding in the Oikopleuridae (Tunicata, Appendicularia). J Zool 181:175-188

Alldredge AL (1979) The chemical composition of macroscopic aggregates in two neritic seas. Limnol Oceanogr 24: 855-866

Alldredge AL (1982) Aggregation of spawning appendicularians in surface windrows. Bull Mar Sci 32:250-254

Alldredge AL, Gotschalk CC (1990) The relative contribution of marine snow of different origins to biological processes in coastal waters. Contin Shelf Res 10:41-58

Alldredge AL, Youngbluth MJ (1985) The significance of macroscopic aggregates (marine snow) as sites for heterotrophic bacterial production in the mesopelagic zone of the subtropical Atlantic. Deep-Sea Res 32:1445-1456

Anakubo T, Murano M (1991) Seasonal variation of zooplankton in Tokyo Bay. J Tokyo Univ Fish 78:145-165

Bedo AW, Acuña JL, Robins D, Harris RP (1993) Grazing in the micron and the sub-micron particle size range: the case of Oikopleura dioica (Appendicularia). Bull Mar Sci 53:2-14

Bochdansky AB, Deibel D, Hatfield EA (1998) Chlorophyll a conversion and gut passage time for the pelagic tunicate Oikopleura vanhoeffeni (Appendicularia). J Plankton Res 20:2179-2197

Bückmann A, Kapp H (1975) Taxonomic characters used for 
the distinction of species of appendicularia. Mitt Hamb Zool Mus Inst 72:201-247

Caron DA, Davis PG, Madin LP, Sieburth JMcN (1986) Enrichment of microbial populations in macroaggregates (marine snow) from surface waters of the North Atlantic. J Mar Res 44:543-565

Clarke C, Roff JC (1990) Abundance and biomass of herbivorous zooplankton off Kingston, Jamaica, with estimates of their annual production. Estuar Coast Shelf Sci 31: 423-437

Davoll PJ, Silver MW (1986) Marine snow aggregates: life history sequence and microbial community of abandoned larvacean houses from Monterey Bay, California. Mar Ecol Prog Ser 33:111-120

Davoll PJ, Youngbluth MJ (1990) Heterotrophic activity on appendicularian (Tunicata: Appendicularia) houses in mesopelagic regions and their potential contribution to particle flux. Deep-Sea Res 37:285-294

Deibel D (1986) Feeding mechanism and house of the appendicularian Oikopleura vanhoeffeni. Mar Biol 93:429-436

Fenaux R (1986) The house of Oikopleura dioica (Tunicata, Appendicularia): structure and functions. Zoomorphology 106:224-231

Fenaux R, Bone Q, Deibel D (1998) Appendicularian distribution and zoogeography. In: Bone Q (ed) The biology of pelagic tunicates. Oxford University Press, Oxford, p 252-264

Flood PR, Deibel D (1998) The appendicularian house. In: Bone Q (ed) The biology of pelagic tunicates. Oxford University Press, Oxford, p 105-124

Fol H (1872) Etudes sur les appendiculaires du Détroit de Messine. Mem Soc Phys Hist Genéve Nat 21:445-499

Gorsky G, Palazzoli I (1989) Aspect de la biologie de l'appendiculaire Oikopleura dioica Fol. 1872 (Chordate: Tunicata). Oceanis 15:39-49

Gorsky G, Fisher NS, Fowler SW (1984) Biogenic debris from the pelagic tunicate, Oikopleura dioica, and its role in the vertical transport of a transuranium element. Estuar Coast Shelf Sci 18:13-23

Hamner WM, Robison BH (1992) In situ observations of giant appendicularians in Monterey Bay. Deep-Sea Res 39: $1299-1313$

Hansen JLS, Kiørboe T, Alldredge AL (1996) Marine snow derived from abandoned larvacean houses: sinking rates, particle content and mechanisms of aggregate formation. Mar Ecol Prog Ser 141:205-215

Hirakawa K, Imamura A, Ikeda T (1992) Seasonal variability in abundance and composition of zooplankton in Toyama Bay, Southern Japan Sea. Bull Jpn Sea Natl Fish Res Inst 42:1-15

Hopcroft RR, Roff JC (1998) Production of tropical larvaceans in Kingston Harbour, Jamaica: are we ignoring an important secondary producer? J Plankton Res 20:557-569

Itoh $\mathrm{H}$ (1990) Seasonal variation of appendicularian fauna off Miho Peninsula, Suruga Bay, central Japan. Bull Plankton Soc Jpn 36:111-119

Lohmann H (1909) Die Gehäuse und Gallertblasen der Appendicularien und ihre Bedeutung für die Erforschung des Lebens in Meer. Verh Dtsch Zool Ges 19:200-239

Mochioka N, Iwamizu M (1996) Diet of anguilloid larvae: leptocephali feed selectively on larvacean houses and fecal pellets. Mar Biol 125:447-452

Nakamura Y (1998) Blooms of tunicates Oikopleura spp. and

Editorial responsibility: Otto Kinne (Editor),

Oldendorf/Luhe, Germany
Dolioletta gegenbauri in the Seto Inland Sea, Japan, during summer. Hydrobiologia 385:183-192

Nakamura Y, Suzuki K, Suzuki S, Hiromi J (1997) Production of Oikopleura dioica (Appendicularia) following a picoplankton 'bloom' in a eutrophic coastal area. J Plankton Res 19:113-124

Ohtsuka S, Kubo N (1991) Larvaceans and their houses as important food for some pelagic copepods. Bull Plankton Soc Jpn (Spec Vol):535-551

Ohtsuka S, Kubo N, Okada M, Gushima K (1993) Attachment and feeding of pelagic copepods on larvacean houses. J Oceanogr 49:115-120

Ohtsuka S, Böttger-Schnack R, Okada M, Onbe T (1996) In situ feeding habits of Oncaea (Copepoda: Poecilostomatoida) from the upper $250 \mathrm{~m}$ of the central Red Sea, with special reference to consumption of appendicularian houses. Bull Plankton Soc Jpn 43:89-105

Paffenhöfer GA (1976) On the biology of Appendicularia of the southeastern North Sea. In: Persoone G, Jaspers E (eds) Proc 10th Eur Symp Mar Biol, Vol 2. Universa Press, Wetteren, p 437-455

Sato R, Yu J, Tanaka Y, Ishimaru T (1999) New apparatuses for cultivation of appendicularians. Plankton Biol Ecol 46: $162-164$

Sato R, Tanaka Y, Ishimaru T (2001) House production by Oikopleura dioica (Tunicata, Appendicularia) under laboratory conditions. J Plankton Res 23:415-423

Seki H (1973) Red tide of Oikopleura in Saanich Inlet. Mer 11: $17-22$

Silver MW, Alldredge AL (1981) Bathypelagic marine snow: deep-sea algal and detrital community. J Mar Res 39: 501-530

Steinberg DK (1995) Diet of copepods (Scopalatum vorax) associated with mesopelagic detritus (giant larvacean houses) in Monterey Bay, California. Mar Biol 122:571-584

Steinberg DK, Silver MW (1994) Midwater zooplankton communities on pelagic detritus (giant larvacean houses) in Monterey Bay, California. Limnol Oceanogr 39:1606-1620

Suzuki R, Ishimaru T (1990) An improved method for the determination of phytoplankton chlorophyll using N,N-dimethylformamide. J Oceanogr Soc Jpn 46:190-194

Taguchi S (1982) Seasonal study of fecal pellets and discarded houses of appendicularia in a subtropical inlet, Kaneohe Bay, Hawaii. Estuar Coast Shelf Sci 14:545-555

Tokioka T (1940) Some additional notes on the Japanese appendicularian fauna. Rec Oceanogr Works Jpn 6:1-26

Tokioka T (1955) General consideration on Japanese appendicularian fauna. Publ Seto Mar Biol Lab 4:251-261

Tokioka T (1960) Studies on the distribution of appendicularians and some thaliaceans of the North Pacific, with some morphological notes. Publ Seto Mar Biol Lab 8:129-221

Tomita M (1998) Seasonal variation in species composition, abundance and diurnal vertical distribution of appendicularians in Toyama Bay, southern Japan Sea, with special reference to Oikopleura longicauda. MS thesis, Hokkaido University, Hakodate

Tomita M, Ikeda T, Shiga N (1999) Production of Oikopleura longicauda (Tunicata: Appendicularia) in Toyama Bay, southern Japan Sea. J Plankton Res 21:2421-2430

Uye S, Ichino S (1995) Seasonal variations in abundance, size composition, biomass and production rate of Oikopleura dioica (Fol) (Tunicata: Appendicularia) in a temperate eutrophic inlet. J Exp Mar Biol Ecol 189:1-11

Submitted: January 3, 2003; Accepted: May 13, 2003

Proofs received from author(s): September 1, 2003 